\title{
Unemployment among Young Graduates in Algeria: A Sociological Reading*
}

\author{
Mohamed Madoui ${ }^{1,2 \#}$ \\ ${ }^{1}$ Conservatoire National des Arts et Métiers (CNAM), Paris, France \\ ${ }^{2}$ Laboratoire Interdisciplinaire de Sociologie Economique (LISE-CNRS, UMR 3320), Paris, France \\ Email: mohamed.madoui@cnam.fr
}

Received 30 August 2015; accepted 8 November 2015; published 11 November 2015

Copyright (c) 2015 by author and Scientific Research Publishing Inc.

This work is licensed under the Creative Commons Attribution International License (CC BY).

http://creativecommons.org/licenses/by/4.0/

(c) (i) Open Access

\begin{abstract}
In the Maghreb region, the unemployment rate of young university graduates is greater than $\mathbf{3 0 \%}$ in Morocco, 30.5\% in Tunisia and 22\% in Algeria (the official figures for 2014 give us $10 \%$ ), which is to say that the issue of unemployment is at the heart of social movements. This phenomenon, which was already at the heart of the Tunisian revolution, has only worsened since then. We can still recall without difficulty the story of Mohamed Bouazizi, a young graduate selling fruits and vegetables as a street vendor, who set himself on fire in late 2010 , preferring death to the social degradation and the disdain with which public authorities looked upon an entire generation of youth whose only expectation was decent work. Unemployed graduates have therefore begun organizing, notably by creating associations to inform public opinion and public authorities about the precarious nature of the current situation and about the continued risk to social cohesion. This article will touch upon three essential points, which are the following: first, an overview of the Algerian labor market will bring to light the characteristics of the working population and the problem of unemployment among young graduates; second, I will take up the issue of how unemployment is experienced and what work means for youth having invested in university study; in the third and final part, I will take up the issue of collective action and forms of mobilization among the unemployed in a country where oil income is used to buy social harmony, and where authorities go to great lengths to defuse the collective struggle of unemployed graduates throughout the country, on some occasions resorting to the use of force, and on others resorting instead to the instrumentalization and discrediting of advocacy organizations for the unemployed.
\end{abstract}

\section{Keywords}

Algeria, Labor Market, Unemployment, Young Graduate, Collective Action

\footnotetext{
*This paper is the product of an introductory conference for a colloquium on the employability and insertion of youth in Algeria, organized by the Faculty of economics and management at the Université de Béjaia, June 4-5, 2014.

"University Professor at the Conservatoire national des arts et métiers (CNAM) and researcher at the Laboratoire interdisciplinaire de sociologie économique (LISE-CNRS, UMR 3320).
} 


\section{Introduction}

As a social phenomenon, the unemployment of young graduates is the object of relatively little study but is increasingly present in the political and media spheres. Because unemployment is considered one of the major causes of the degradation of social ties, even young graduates experience unemployment as a kind of social disqualification, humiliation or social disdain. Sociological study has already shed light upon the consequences of unemployment as a social ordeal [1] [2] involving not only a degraded lifestyle but also a weakening of social life, concurrent with marginalization from the working world [3]-[5]. Through this paper, I therefore hope to improve our understanding of how collective identities can currently be transformed through the experience of unemployment.

In the Maghreb region, the unemployment rate of young university graduates is greater than $30 \%$ in Morocco ${ }^{1}$, $30.5 \%$ in Tunisia ${ }^{2}$ and $22 \%$ in Algeria $^{3}$ (the official figures for 2014 give us $10 \%$ ), which is to say that the issue of unemployment is at the heart of social movements. This phenomenon, which was already at the heart of the Tunisian revolution, has only worsened since then. We can still recall without difficulty the story of Mohamed Bouazizi, a young graduate selling fruits and vegetables as a street vendor, who set himself on fire in late 2010, preferring death to the social degradation and the disdain with which public authorities looked upon an entire generation of youth whose only expectation was decent work. Unemployed graduates have therefore begun organizing, notably by creating associations to inform public opinion and public authorities about the precarious nature of the current situation and about the continued risk to social cohesion. The Association nationale des diplômés chômeurs au Maroc (ANDCM), created in 1991 in Morocco, is one such association. Other examples include the Comité national des diplômés chômeurs (CNDC) in Algeria, the Union des diplômés chômeurs in Tunisia, and the Association mauritanienne des diplômés chômeurs (AMDC) in Mauritania. The very creation of these associations demonstrates the extent to which unemployment has become an omnipresent motive for protest throughout the Maghreb region [6] [7]. A forum for the fight against unemployment and precarious work was to be organized in Algiers in February 2013, to coordinate collective action at the regional level and the mobilization of young unemployed graduates in the Maghreb. This initiative was not warmly welcomed by public authorities, however, who did not hesitate to ban the forum and to expel, manu militari, the Moroccan, Tunisian and Mauritanian delegates. The episode illustrates the fear which unemployment inspired among Algerian authorities, who saw unemployment as catalyzing social protest and weakening the established social order. By taking this observation as my starting point, my contribution will touch upon three essential points, which are the following: first, an overview of the Algerian labor market will bring to light the characteristics of the working population and the problem of unemployment among young graduates; second, I will take up the issue of how unemployment is experienced and what work means for youth having invested in university study; in the third and final part, I will take up the issue of collective action and forms of mobilization among the unemployed in a country where oil income is used to buy social harmony, and where authorities go to great lengths to defuse the collective struggle of unemployed graduates throughout the country, on some occasions resorting to the use of force, and on other others resorting instead to the instrumentalization and discrediting of advocacy organizations for the unemployed.

\section{Overview of the Labor Market in Algeria}

We should note from the outset that very little work exists in Algeria concerning unemployment in general and the unemployment of young graduates particularly. With the exception of a limited number of articles, written communications and doctoral dissertations on employment and the characteristics of the labor market in Algeria, written for the most part from an economics perspective [8]-[12], there is hardly any in-depth sociological research on unemployment among young graduates. Some data taken from the Office national des statistiques (ONS) will help us to highlight certain characteristics of the Algerian labor market. In April 2013, the labor force, as defined by the ILO, stood at 11,716,000 people. Of these, more than two million (2,288,000 people) were women, who thus comprised $19.5 \%$ of the overall labor force. Women's access to education, and especially to higher education, was highly determinative of women's participation in the labor market. The activity rate among the Algerian population, aged 15 years or older, stood at $45 \%$ overall, at $66.3 \%$ for men and at $16.3 \%$ for

\footnotetext{
${ }^{1}$ Direction de la statistique, Activité, emploi et chômage, 2006, Morocco.

${ }^{2}$ Institut national des statistiques.

${ }^{3}$ Office national des statistiques.
} 
women (Table 1). While important gender disparities therefore existed, the gap was narrower when education levels were higher. Thus the gap in activity rate stood at nearly 50\% among workers with no university degree and at $14.1 \%$ among university graduates. Women's access to education, and particularly to higher education, therefore heavily influenced women's participation in the labor market. Women were most commonly employed by the public sector, which accounted for $61.2 \%$ of the total employment of women.

Through the end of the 1990s, among countries with equivalent levels of per capita income, Algeria ranked as one of the most burdened by unemployment. Between 1990 and 2000, unemployment reached more than 20\% of the active labor force. Today, if we take the statistics published by the Office national des statistiques (ONS, April 2014) at face value, the unemployment rate stands at $9.8 \%$, or approximately one half of what it was during that period. The unemployed population, as defined by the ILO, is estimated today at 1,151,000 people, whereas it stood at more than 2 million people in 1995. Unemployment statistics bring other age, gender and educational disparities to light. In April 2014, the unemployment rate stood at 8.8\% among men and 14.2\% among women. However the unemployment rate among women dropped significantly in 2014, after reaching $16.3 \%$ the previous year. Unemployment was also higher in urban areas (10.7\%) than in rural areas (8.7\%).

However, the most determinative factor with respect to these unemployment trends was the level of education attained, and more specifically, the type of degree earned. The unemployment rate of young university graduates has continuously dropped, falling from $21.4 \%$ in 2010, to $14.3 \%$ in 2013, to 13\% in April 2014. These figures

Table 1. Selected key indicators of the labor market (in \%).

\begin{tabular}{|c|c|c|c|}
\hline & Male & Female & Total \\
\hline \multicolumn{4}{|l|}{ Activity rate } \\
\hline 15 years and above & 66.3 & 16.3 & 41.5 \\
\hline 15 - 24 years & 42.3 & 8.7 & 25.7 \\
\hline 25 - 54 years & 89.4 & 23.6 & 56.3 \\
\hline 25 - 34 years & 89.4 & 30.5 & 60.8 \\
\hline 35 - 54 years & 89.3 & 18.8 & 52.9 \\
\hline 15 - 59 years & 74.0 & 18.3 & 46.2 \\
\hline 60 and above & 16.6 & 1.8 & 9.6 \\
\hline 55 - 59 years & 62.5 & 6.2 & 34.8 \\
\hline 55 - 64 years & 47.6 & 4.9 & 27.2 \\
\hline 65 and above & 8.9 & 1.0 & 5.1 \\
\hline \multicolumn{4}{|l|}{ Ratio employment/population } \\
\hline 15 years and above & 60.5 & 14.0 & 37.5 \\
\hline 15 - 24 years & 32.8 & 5.5 & 19.3 \\
\hline 25 years and above & 69.9 & 16.9 & 43.5 \\
\hline \multicolumn{4}{|l|}{ Unemployment rate } \\
\hline Global & 8.8 & 14.2 & 9.8 \\
\hline Youth (16 - 24 years) & 22.4 & 36.7 & 24.8 \\
\hline Adults (25 years and above) & 6.1 & 10.8 & 7.1 \\
\hline Relation between unemployment rates among youth and adults & 3.7 & 3.4 & 3.5 \\
\hline Proportion of total unemployed who are youth & 41.2 & 34.2 & 39.3 \\
\hline Proportion of youth who are unemployed (15 - 24 years) & 9.5 & 3.2 & 6.4 \\
\hline Rate of long-term unemployment & 6.0 & 8.9 & 6.6 \\
\hline Incidence of long-term unemployment & 66.8 & 58.7 & 64.5 \\
\hline \% of youth, 15 - 24 years of age, neither in the labor force nor in school & 13.3 & 35.8 & 24.4 \\
\hline
\end{tabular}

Source: Enquête Emploi-Chômage, April 2014, Office National des Statistiques. 
should be treated with caution in light of the amount of underemployment, particularly among Algerian youth searching for their first job. Nonetheless, salaried work remains the dominant form of employment, with two out of three workers (65.3\%) engaged in salaried employment relationships. The trend toward self-employment was therefore remained limited. The vast majority of employees worked in the service sector (61.4\%), followed by construction (16.5\%), industry (12.6\%) and agriculture (9.5\%). Industry, which fueled economic growth in Algeria in the 1970s, thus lost its role as the country's major source of employment. Agriculture has lost much of its posture, with rural flight dragging agricultural employment from 50\% of total employment in 1967 to $10 \%$ in 2014 .

According to a recent report by the Algerian Conseil économique et social (CNES), unemployment stood at $24.8 \%$ among youth between 16 and 24 years of age (1 of every 4 young workers) and at $16.1 \%$ among university graduates. The ILO recently put forward figures of $21.4 \%$ for Algeria, $18.9 \%$ for Egypt and $17.4 \%$ for Morocco. With respect to the influence of education level upon unemployment, the unemployment rate among youth having little or no education can be observed as dropping, while the unemployment rate among young graduates can be observed as rising (Table 2). With regard to placement in the labor market, the trend is contrary to that which is most commonly observed in developed countries: young graduates in Algeria are at higher risk of unemployment, even though their diplomas are logically supposed to afford them better protection from that very risk. Furthermore, employment prospects for university graduates are not encouraging. One explanation for this phenomenon is that the skills developed through university education are of little relevance to the needs observed in corporations or public administrations. The educational system and universities are increasingly disconnected from the labor market, to the point that it is easier for the latter to integrate workers with little or no education (Bouklia-Hassane et Talahite, 2008) [10].

Algerian companies complain of difficulty in finding suitable employment candidates among university graduates, concluding that universities do not adequately prepare students to meet business needs. Universities in turn complain that companies are rarely specific enough when it comes to articulating their needs in terms of skills. As these two worlds thus turn their backs on each other, young graduates are left in great difficulty when it comes to finding qualified employment, with the exception of public-sector employment. Moving from one odd job to the next, these young graduates often rationalize their precarious employment situation as figuring within the rite of passage into decent, qualified employment. This disconnect between the educational system and the working world has numerous consequences [10]

- A waste of human resources, as a largely state-financed investment in human capital is not used in such a way as to contribute significantly to economic growth;

- Unemployment among young graduates impacts individual behavior, as youth increasingly chose to forego education in order to improve their chances of finding formal or informal employment and developing meaningful professional experience;

- Students increasingly prefer to prolong their studies in order to avoid entering the job market and confronting the difficulty of finding employment.

Table 2. Unemployment rate by level of education, degree obtained, and gender (\%).

\begin{tabular}{|c|c|c|c|}
\hline & Male & Female & Total \\
\hline \multicolumn{4}{|l|}{ Level of education } \\
\hline No education & 2.9 & 4.3 & 3.1 \\
\hline Primary & 7.3 & 8.8 & 7.4 \\
\hline Intermediary & 11.2 & 16.2 & 11.7 \\
\hline Secondary & 7.4 & 14.1 & 8.9 \\
\hline Higher Education & 9.7 & 15.9 & 12.6 \\
\hline \multicolumn{4}{|l|}{ Degree attained } \\
\hline No degree & 8.2 & 10.7 & 8.5 \\
\hline Vocational degree & 10.2 & 16.7 & 11.9 \\
\hline University degree & 10.0 & 15.9 & 13.0 \\
\hline TOTAL & 8.8 & 14.2 & 9.8 \\
\hline
\end{tabular}

Source: Enquête Emploi-Chômage, April 2014, Office National des Statistiques. 
Governmental authorities attempt to respond to these concerns by improving existing job-placement programs. Thus, for example, persons benefitting from the Dispositif d'attente à l'insertion professionnelle (DIAP), which is open to young university graduates along with high-level technicians and other qualified job-placement candidates, will be eligible for a renewable three-year contracts instead of one-year contracts when their employer is a public administration. Similarly, persons who sign a special graduate-placement contract with a private company are given a new right to renew their contract for a twelve-month period. Within the framework of this program, referred to as the Contrat de travail aidé (CTA), young graduates and high-level technicians are placed within companies for three-year terms during which their salary is publicly subsidized. Former employees of the public education system gain the new right to be placed within a company for three years instead of two, during which the company will continue to receive the same level of public subsidy. The government strongly encourages companies to give priority to young graduates in their recruitment process. Furthermore, governmental aid programs exist for those companies which indeed recruit young graduates. These aids may take the form of reduced employer charges or reduced social security charges.

In light of the massive unemployment which is increasingly affecting qualified workers, the Algerian government has also created programs to encourage the development of entrepreneurship as a means for stemming the unemployment of graduates [13]. The Agence nationale de soutien à l'emploi des jeunes (ANSEJ) was created in 1998 for the benefit of unemployed young graduates between 18 and 35 years of age. Between 2010 and 2013, some 378,250 jobs were created as part of this program, spread out among all of the different major sectors of activity, including the service sector (e.g., the transportation of passengers or merchandise), agriculture, traditional handicraft, construction, liberal professions, fishery, etc.

Another example is the Agence nationale de gestion du micro-crédit (ANGEM), a micro-lending program set up by the CNAC for the benefit of unemployed persons between 30 and 50 years of age, for the purpose of helping these beneficiaries gain access to bank financing. This type of program most often benefits women who are able to use micro-lending as an opportunity to gain new economic and social standing. For some, such programs offer a way to transition into their desired occupation; others take interest for the purpose of meeting a financial need. However, among women benefitting from ANGEM loans, the trend is to use the funds to get started in one of a number of traditional occupations: tailoring, embroidery, baking and other kinds of food preparation. Oftentimes the work in question can be carried out at home, which is often an important factor for mothers.

In spite of this accumulation of government programs, the results in terms of real jobs remain scarce. By fighting exclusion at all costs, sometimes one runs the risk of creating more exclusion. Failing to satisfy the specific criteria of any existing government program, some youth in great difficulty fall through the cracks. Furthermore, to accept help from a government program, one must first recognize and accept a social handicap which limits employability. Finally, the resulting stigmatization can give rise to still more discrimination, which may potentially be even more severe.

Having thus set the stage, we shall now proceed to discuss how unemployment is experienced by the young graduates themselves.

\section{The Unemployment Ordeal, or What It Means to Be "Without Work"}

Preferring to study the subjective dimensions of unemployment, sociologists have long been content to let economists study the structural mechanisms responsible for creating unemployment. Consequently, there is a sort of scientific division of labor. Economists develop the theories of unemployment and define the factors which lead to a shortage of employment. Sociologists, meanwhile, focus on the experiences and the sentiments of the unemployed, as well as the meaning which society attributes to the deprivation of employment.

Nonetheless, because unemployment is often considered one of the major causes of the disaggregation of social binds, social scientists pay attention to it. Unemployment is often studied as a process involving the progressive accumulation of handicaps. The first major sociological studies of unemployment, including Paul Lazarsfeld's study in Austria, were carried out in the 1930s, during a period which would be remembered for economic hardship and peaks of unemployment.

A group of sociologists led by Paul Lazarsfeld ${ }^{4}$ [1], a researcher who would gain worldwide renown after his emigration to the United States, carried out a study in Marienthal, a small town in Austria, to discover the extent

${ }^{4}$ Les chômeurs de Marienthal, Paris, Minuit, 1981 (original edition, 1932). 
to which unemployment produced discouragement and isolation. Because employment set the pace for most daily activities, it served as an important reference point in the organization of daily life and as a driving force for social life. With unemployment, there was more free time, but fatigue and lassitude often won out despite the multiple leisure activities in which unemployed persons could engage (theatre, cinema, city library, etc.).

These issues would garner significantly less academic attention during the period spanning from the mid-1940s to the mid-1970s. Raymond Ledrut's [14] work was exceptional in this respect but went largely unnoticed, as unemployment during this period was perceived as a short-term cyclical phenomenon. Interest in unemployment would not pick up again among economists and sociologists, as well as among the makers of social policy, until after two oil crises at the end of the 1970s [5].

In France, a book by D. Schnapper likening unemployment to an "ordeal” [2] would mark the beginning of a lasting academic interest in unemployment research. Schnapper's work still serves as a major reference today, both because of its content and because of its methodological approach (through semi-directive interviews, the researcher learns how to construct a typology of personal experiences).

L'Épreuve du chômage is based on the semi-directive interviews of approximately 100 unemployed persons, carried out between November 1978 and June 1980, which allow the author to analyze different social groups' attitude toward unemployment. On this sensitive topic, Serge Paugam [5] has observed that two visions are too often mutually opposed, the first of which is sympathetic and attentive to the psychological distress of the unemployed, while the second vision focuses on their personal responsibility for their situation.

The state of being unemployed can be characterized by three common traits, which are the lack of participation in collective activities and in collective pacing (work/non-work, week/weekend, etc.), a loss of bearing (the way to work, to the hairdresser, to the bank, etc.) and new doubts about personal and social identity, which vary considerably based on one's attitude toward work. However, in spite of these common characteristics, there is still an extreme diversity of possible ways to experience unemployment, which may also depend on one's aptitude for finding substitute activities, on the size and density of one's social network and on one's family's integration capacity. D. Schnapper thus distinguishes ideal-types of unemployment:

Total unemployment, which is characterized by boredom, de-socialization and shame. Such is the experience of the majority of manual workers, of some employees and to a lesser degree of some executives of humble origin. In other words, this type of experience is most common among people who see their work as representing everything: not just a means for making a living, but also a purpose for living, a means for feeling useful and a basis for social recognition [5]. Next there is "inversed" unemployment (le chômage inversé), which essentially concerns a young population with a middle-class or even upper-class social background, and which is experienced as a "long vacation"-as a way of having more time for oneself, for hobbies and for leisure activities. Finally, there is "deferred" unemployment, which is observed mostly among a category of executives who, refusing to endure unemployment as an ordeal, continue to behave as if they are a part of the active workforce and to adhere to the norms of the working world.

To the extent that socialization allows individuals to weave together the multiple networks to which they belong, the rupture of one social bond can often bring about the disaggregation of multiple others. Serge Paugam [5] thus describes four principal types of social bonds.

The filial bond, which involves the solidarity between parents and children, constitutes one such type. This solidarity is relatively fragile and can become undone during times of unemployment. Bonds of elective participation involve extra-familial socialization in which individuals come into contact with other individuals whom they meet within diverse groups and institutions. The unemployment ordeal undermines these bonds of elective participation as well. Bonds of organic participation are those which take form at school and persist into the working world, where unemployment can therefore bring about at least partial rupture. Finally, there is the bond of citizenship, which is based upon the principle of belonging to a State or a nation. Civic life entails such activities as voting, activism, commitment, helping to build civil society, etc. Unemployment weakens this bond too, often because unemployed persons lose interest little by little in such forms of participation in social life, isolating themselves instead.

In the few informal interviews which I have had the occasion to conduct with young graduates in Algeria, feelings of de-socialization were expressed every time. Unemployed young graduates perceive themselves as the objects of social disdain and sometimes feel ashamed by the idea of not working despite having a diploma. The familial gaze is undoubtedly the most difficult to face up to, as parents-especially working-class parents-have often invested enormous hope into the education and qualification of their children, for the purpose of helping 
their children to avoid low-paid and tedious manual or farm work. Kamel, who is 25 years old, who has a degree in sociology from the Université de Béjaia, and who has been unemployed ever since he earned his degree in 2011, put it as follows: "The hardest part is accepting how my family must see me. They had a lot of hope for my education. Today, it hurts them to see me unemployed with a university degree. I knocked on all of the doors though to find work, but still nothing. I feel like I'm a burden to my family. It's not normal at my age to be asking my father for money to buy my cigarettes or my clothes. The hardest thing is the way other people see you as a good-for-nothing. So I end up accepting whatever work I can find, which is usually work requiring no skills whatsoever, but which I have to do to make a little money. But psychologically it's hard to endure working with unskilled colleagues when you've got a university degree to your name. I feel like I've wasted my time.”5

Yacine, who is 27 years old, who has a Master's degree in management, has a similar outlook after an accumulation of periods of unemployment interspersed between various odd jobs. He has never been able find a job corresponding to his level of qualification. "By continuing to the Master's level, I thought I would be armed against unemployment and that I would quickly find work in the human-resources management field in a private or public firm. Despite sending numerous CVs, I was only contacted for a few interviews which ultimately did not lead to anything. Every time, they tell you they'll call you but they never do. Here in Algeria, it's all about your connections. Your degrees don't matter. What matters is whether you know someone with power who can find you decent, well-paid work. Unfortunately, that's not my case. I'm a farmer's son who doesn't know anyone who can help me to find work... After so many periods of unemployment, you become bitter and you hold it against everyone. My parents are the first in line to give me a negative image of myself, not to mention the many others who see at you as living at their expense... I've seen kids stop studying after middle school or high school and go on to be more successful than I am. I finally end up asking myself why I studied so much for nothing, if at the end of the day they're only willing to give me unskilled work... I'm absolutely livid!”,

Unemployment is often associated with "social death" and shame. Djamel, who is 28 years old and who has a Master's degree in information technology, evokes these phenomena when recalling his long period of unemployment: "For me, unemployment, especially when you've got a university degree, is a kind of waste, a social death. I spent days doing nothing. The hardest part was the shame you feel whenever someone asks you what you do for a living. At first I would say I was looking for work or I would make up something, like "I work from home”... Since I work with computers, people would think I really work from home. Sometimes, I'm really ashamed of my situation. The hardest thing to endure is how my family sees me. They have ways of making me understand that my presence is superfluous and that I've become dead weight. T be out of work is like dying a little. Sometimes I feel useless. I really hold it against our leaders. What is the point of educating generations of youth if you can't guarantee them work? I don't have anyone in my family with connections who could help me to find work. It's a modest family, and that's why I'm really furious with the State."

Sociological work analyzing individual careers has already pointed out the dialectic that links social status

\footnotetext{
5“Le plus dur est de supporter le regard de la famille qui a mis beaucoup d'espoir dans mes études. Aujourd'hui, ils souffrent de me voir au chômage alors que j'ai une licence. J'ai pourtant frappé à toutes les portes pour trouver du travail, mais toujours rien. J'ai l'impression d'être un fardeau pour ma famille. Ce n'est pas normal qu'à mon âge, je demande de l'argent à mon père pour acheter mes cigarettes ou mes vêtements. Le plus dur c'est le regard des autres qui te considèrent comme un vaut- rien. Du coup j'accepte n'importe quel boulot le plus souvent des boulots qui ne demandent aucune qualification et que je dois faire pour gagner un peu d'argent. Mais psychologiquement c'est dur à supporter de travailler avec des personnes non qualifiées alors que moi j'ai une licence en poche. J'ai l'impression d'avoir perdu mon temps."

${ }^{6}$ “En allant jusqu'au master, je pensais que j'étais armé contre le chômage et que je trouverai rapidement un travail dans le domaine de la gestion des ressources humaines dans une entreprise privée ou publique. Malgré les nombreuses candidatures spontanées, je n'ai décroché que quelques entretiens qui n'ont débouché sur rien..A chaque fois on vous dit qu'on va vous rappeler mais toujours rien. Ici en Algérie, il n'y a que le piston qui marche, peu importe si vous êtes diplômé ou pas, l'essentiel est d'avoir quelqu'un qui a du pouvoir et qui pourra vous trouver un travail décent et bien rémunéré. Malheureusement, ce n'est pas mon cas, je suis fils de paysan qui n'a aucune relation pour pouvoir trouver un travail... Pendant toutes ces périodes de chômage, on devient aigri et on en veut à tout le monde. Mes parents sont les premiers à me renvoyer une image négative de moi-même sans parler des autres qui vous regardent comme si vous êtes à leur charge...J'ai vu des jeunes qui ont arrêté leurs études au niveau du collège ou du lycée qui réussissent mieux que moi. Je me demande finalement pourquoi j’ai fait toutes ces études pour rien si au final on ne me propose que des emplois de faible qualification...J'ai vraiment la rage!”

7"Pour moi le chômage surtout quand on est diplômé est une sorte de gâchis, une mort sociale. Je passais mes journées à ne rien faire, et le plus dur dans tout ça est la honte qu'on ressent à chaque fois qu'on me demande ce que je fais dans la vie. Au début, je disais que je recherchais du travail ou j'inventais des activités style travail à domicile...Comme je suis informaticien, les gens croyaient que je travaille en effet à la maison. Parfois, j'ai vraiment honte de ma situation, c'est surtout le regard de la famille qui est dur à supporter. On me fait comprendre que je suis en trop et que je suis un boulet pour eux. Ne pas travailler c'est vraiment mourir un peu. Je me sens parfois inutile. J'en veux beaucoup à nos dirigeants car à quoi sert de former des générations de jeunes si on ne leur garantit pas un emploi. Moi je n'ai personne dans ma famille qui pourrait me pistonner et m'aider à trouver un travail. C'est une famille modeste et c'est pour cela que j'ai vraiment la rage envers l'Etat".
} 
and modes of employment. As Djamel rightly points out, an individual's social environment weighs heavily upon his professional fate. Today we appreciate the extent to which family plays an important role in laying the groundwork for professional activity or in choosing the most promising line of work when entering the labor market for the first time. Employers themselves prefer to fall back upon a network of acquaintances (friends, professional acquaintances, alumni associations, etc.) rather than resorting to placement agencies or public services (Pôle emploi). The employer is thus better assured of the reliability and the social integration of the employee whom he recruits [15].

Social capital also plays an important role. Pierre Bourdieu [16] defines it as the set of actual or potential resources of an enduring network of more or less institutionalized relations of mutual knowledge and mutual recognition; or in other words, as belonging to a group as a set of agents who are not only endowed with common properties, but are also united by permanent and useful bonds. ${ }^{8}$

The amount of social capital which a particular individual possesses depends on the extent of the network of relations which he can effectively call upon, and on the amount of capital (economic, cultural symbolic) possessed by each of the people to whom he is connected. In other words, a network of relationships is the product of strategies of social investment which must be maintained in order to produce enduring and useful bonds. According to P. Bourdieu, the uses to which social capital might be put multiply the effects of domination resulting from the possession of economic and cultural capital.

In his seminal article on the strength of weak ties, M. Granovetter [17] [18] underscores the fundamental role of social networks in economic action. He contrasts weak ties and strong ties, arguing that weak ties are a means for individuals to seize certain opportunities which open up to them, while strong ties engender social cohesion and translate into a fragmentation of the social whole. The means used by individuals to find employment are of three different categories: direct contact (sending an unsolicited CV); formal application (responding to an ad); personal contacts (the applicant and the employer enter into contact via an intermediary whom they both know). In his questionnaire-based study (266 respondents) on the means employed by executives and technicians to find a job, 56\% succeeded thanks to personal contacts (of which 31\% succeeded through family contacts and 69\% through professional contacts); 19\% succeeded through formal application (ads, placement agencies); 19\% succeeded through direct contact (unsolicited CVs). Weak ties are therefore more efficient than strong ones (a thesis which Bourdieu would criticize as encouraging alienation).

Granovetter's work would later be reproduced in France by Michel Forsé. ${ }^{9}$ [19] Using data from a 1994 study conducted by the Institut national de la statistique et des études économiques (INSEE), he reaches similar conclusions. Nearly $35 \%$ of respondents found work thanks to the social capital which they were able to call upon: family (6.3\%), personal relations (19.5\%), school or training organization (4.1\%) or some pre-existing relationship with the employer (5.7\%). The French Agence nationale pour l'emploi (ANPE) and other placement organizations account for $13.3 \%$ of total cases. If it is difficult to distinguish weak ties from strong ones with precision on the basis of this data, it would nonetheless appear that family support (strong ties) is most solicited by rural youth with relatively low levels of education, belonging to the working class. Alumni networks (weak ties) are, on the other hand, more heavily solicited by urban youth with degrees who are situated relatively high on the social ladder.

In Algeria, it would undoubtedly be useful to conduct a similar, more ambitious study, for the purpose of analyzing the extent to which social capital weighs upon the professional insertion of youth, and comparing the ways in which graduates from working-class environments and graduates from upper-class environments experience unemployment.

\section{Collective Action and Forms of Mobilization among the Unemployed}

Unemployed youth, including a considerable proportion of young graduates, are increasingly finding ways of organizing themselves, creating associations capable of sensitizing public opinion and government authorities to their condition as unemployed youth, and communicating their demands. Behind the unemployment statistics

\footnotetext{
${ }^{8}$ Actes de la recherche en sciences sociales, n 31 , January 1980 . Bourdieu writes: “l'ensemble des ressources actuelles ou potentielles d'un réseau durable de relations plus ou moins institutionnalisées d'interconnaissance et d'inter-reconnaissance; ou en d'autres termes, à l'appartenance à un groupe comme ensemble d'agents qui ne sont pas seulement dotés de propriétés communes, mais sont aussi unis par des liaisons permanentes et utiles".

${ }^{9}$ M. Forsé, “Capital social et emploi”, L’année sociologique, 1997; see also “Rôle spécifique et croissance du capital social”, Revue de l'Observatoire française des conjonctures économiques (OFCE), January 2001.
} 
and the polemicizing which informs public debates, the face of the typical unemployed person is growing younger-under thirty years old, often with a university degree, looking for work for over a year, with only an accumulation of odd jobs as experience. This "dirty work" (sales boulots), as they call it (subsidized employment in local government, warehouseman, deliverer, proctor in a local school), is the common lot for youth who are desperately waiting for more stable and better-paying opportunities, which never seem to arrive despite the economic recovery which the country has been enjoying for the past fifteen years.

The infuriated unemployed are swinging into action. Throughout the country, graduates are taking responsibility rather than remaining silent. In Laghouat, young graduates gathered in front of the Agence nationale de l'emploi (ANEM) in February 2013 to burn their diplomas. It was a strong symbolic gesture which should remind us of another social drama - that of undocumented workers, the "harragas", who also burned their papers, burned their identities, and sometimes even their bodies as they covertly cross the Mediterranean. Sometimes, young graduates are among them, braving danger in hopes of finding a better life. This desperate gest shows the extent to which unemployment acts as a time bomb, even if government attempts to defuse it by instrumentalizing the popular movements that grow among unemployed people, or by simply buying social harmony through the multiplication of aid programs (subsidized employment, self-employment, etc.) which only serve to further confine youth to conditions of precarious employment.

Despite the instrumentalization and the subterfuge that the system mobilizes to disrupt social solidarity among the unemployed (going so far as to accuse CNDDC leader Tahar Belabès of conspiring against the government), the movement persists, resisting all attempts to stifle or to hijack it. Albert Hirschman's contribution (Exit, Voice, and Loyalty: Responses to Decline in Firms, Organizations and States, Harvard University Press, 1970) is interesting here as it helps to account for this movement's capacity to refuse defection ("exit”) and to make itself heard ("voice") when it comes to claiming the right to stable and decent employment. Citizens and progressives prefer to voice these claims and do so ways that range from simple public demonstrations of objection to direct and violent confrontation with public authorities. ${ }^{10}$

The collective frustration which is at the root of the wave of political "revolutions" in the Arab States as well as the subsequent political and social protest movements (demonstrations, sit-ins, strikes), cannot be analyzed and understood unless we are able to explore collective representations, including notably the way in which social justice and the role of the State as the guarantor of equal dignity and equal opportunity among citizens [20].

\section{Conclusions}

The different studies dedicated to unemployment show the experience for unemployed individuals is difficult, and sometimes even traumatic. Employment offers people status, a place in society, and an identity of value [21]. Employed people feel recognized in their families, in their neighborhoods and in their societies. On the other hand, the lack of employment is associated with negative, depreciative images. The unemployed are frequently perceived as lazy, parasitic and, as Robert Castel put it, "useless to the world" ("inutiles au monde"). Such individuals form a group which we can characterize as "stigmatized". This stigmatization can be understood in light of the central place where work has come to occupy in our lives. First and foremost, being unemployed is the deprivation of a salary, of the principal source of income for a family. But beyond this deprivation of salary, unemployment entails removal from the indispensable socializing effects of work, which offers individuals a context in which to set goals and give meaning to their lives, including notably the meaning that comes from being useful to society. It is this same social usefulness which accounts for social status, position and identity. Being unemployed in a world, where work is held up as a true institution inevitably, results in a severe identity crisis [22] [23].

We can therefore understand why young graduates are getting mobilizing, voicing their claims and taking the floor to express their dismay at the increasingly worrisome risks of unemployment. Today's youth, and particularly the graduates among them [7] [24] [25], are demanding access not only to employment, but by extension to real citizenship that is not a mere legal fiction. Their demands express the extent of their frustration with the gap between social ideals and expectations on the one hand, and the limited effects of the State's redistributive action on the other hand, along with the resulting in a political model which has gradually given way to cronyism

\footnotetext{
${ }^{10}$ Laroussi Amri has adopted Hirschmann's concepts of exit (défection) and voice (prise de parole) in work on social movements in Tunisia. See his intervention on unemplyment among young Tunisian graduates, "Le chômage des diplômés Tunisiens" at the seminar organized by the Institut de recherche sur le Maghreb contemporain (IRMC), June 16-17, 2013, on unemployment and the forms of mobilization among the unemployed in the Maghreb.
} 
and nepotism [26].

\section{References}

[1] Lazarsfeld, P. (1982) Les chômeurs de Marienthal. Edition Originale 1932, Minuit, Paris.

[2] Schnapper, D. (1981) L’épreuve du chômage. Gallimard, Paris.

[3] Bennarosh, Y. (2014) Les sens du travail. Migration, reconversion, chômage. Presses universitaires de Rennes (PUR), coll. "Le sens social".

[4] Bennarosh, Y. (2007) Le travail vu du chômage, une comparaison hommes-Femmes, français(e)s et migrant(e)s. In: Meulders, D. (dir), Marché du travail et genre dans les pays du Maghreb. Quels marchés du travail? Documents du MAGE N¹1, 101-130.

[5] Paugam, S. (2006) L’épreuve du chômage. Une rupture cumulative des liens sociaux. Revue Européenne des Sciences Sociales, XLIV, 11-27. http://dx.doi.org/10.4000/ress.248

[6] Baamara, L. (2012) (Més)aventures d'une coalition contestataire: Le cas de la Coordination nationale pour le changement et la démocratie (CNCD) en Algérie. L’Année du Maghreb, VIII.

[7] Emperador, B. (2007) Diplômés chômeurs au Maroc: Dynamiques de pérennisation d’une action collective plurielle. L’Année du Maghreb, III, 297-311.

[8] Arhab, B. (2010) Contribution à la réflexion sur la promotion de l'emploi et la lutte contre le chômage en Algérie: étude analytique et empirique. Doctoral Dissertation in Economics, Université de Béjaïa, Béjaïa.

[9] Benhabib, L. (2013) Le chômage des jeunes en Algérie: l'enjeu des inégalités de diplôme et de genre. Communication for the 30th "Journées du développement", entitled "Ethique, entrepreneuriat et développement”, Association Tiers-Monde, Université Cadi Ayyad, Marrakech, 29-31 May.

[10] Bouklia-Hassan, R. and Talahite, F. (2008) Marché du travail, régulation et croissance économique en Algérie. Revue Tiers-Monde, No. 194, 413-437. http://dx.doi.org/10.3917/rtm.194.0413

[11] Bouyacoub, A. (2002) Emploi, formation et employabilité en Algérie: Quelle problématique? Conférence euromaghrébine sur la formation, International Labor Organization (ILO), Algiers, 27-29 April.

[12] Musette, M.S. (2013) Le marché du travail en Algérie: Une vision nouvelle? Communication aux journées de l'entreprise algérienne: Emploi, formation et employabilité, Algiers, 29 October 2013.

[13] Madoui, M. (2012) Entreprises et entrepreneurs en Algérie et dans l’immigration. Essai de sociologie économique. Karthala, Paris.

[14] Ledrut, R. (1966) Sociologie du chômage. PUF, Paris.

[15] Lallement, M. (2007) Le travail, une sociologie contemporaine. Gallimard, Paris.

[16] Bourdieu, P. (1980) Le capital social: Notes provisoires. Actes de la recherche en sciences sociales, No. 31.

[17] Granovetter, M. (2000) Le marché autrement. Desclée de Brouwer, Paris.

[18] Granovetter, M. (1985) Economic Action and Social Structure: The Problem of the Embeddedness. American Journal of Sociology, 91, 481-510. http://dx.doi.org/10.1086/228311

[19] Forse, M. (1997) Capital social et emploi. L’Année Sociologique, 47, 143-181.

[20] Melliti, I. (2014) Économies morales et légitimités politiques au Maghreb. Perspectives comparées sur les sentiments d'injustice et le bien commun. Le Carnet de l'IRMC, 24 January 2014. http://irmc.hypotheses.org/1358

[21] Bourguignon, D. and Herman, G. (2007) Le chômage analysé à la lumière de la stigmatisation. In: Herman, G., Travail, chômage et stigmatisation, De Boeck Supérieur, Paris, 145-176.

[22] Dubar, C. (2000) La crise des identités. L’interprétation d’une mutation. PUF, Paris.

[23] Sainsaulieu, R. (1985) L’identité au travail. FNSP, Paris.

[24] BEN SEDRINE \& GEISSER (1997) Les diplômés à la sortie de l’université. Monde Arabe-Maghreb-Machrek, No. $157,17-28$.

[25] Hafaïedh, A. (2000) Trajectoires de chômeurs diplômés en Tunisie: L’attente, l’ailleurs et la conversion. In: Geisser, V., Dir., Diplômés maghrébins d'ici et d'ailleurs, CNRS, Paris, 122-136.

[26] Melliti, I. (2011) Les jeunes et le travail en Tunisie. In: Vultur, M. and Mercure, D., Dir., Perspectives internationales sur le travail des jeunes, Les Presses de l’Université Laval, Québec, 87-106. 